\title{
Relative Infiltration Rate of Puerto Rican Soils
}

\author{
M. A. Lugo López, J. Juárez, Jr., and J. A. Bonnet ${ }^{1}$
}

\section{INTRODUCTION}

The rate of water infiltration is one of the most valuable and practical soil characteristics. It is defined as the volume of water that enters the soil profile within a given time unit. Knowledge on the water intake rate is essential in planning and designing irrigation projects and drainage systems. Infiltration rate is a function of soil properties and management. Among the most important soil properties influencing infiltration are bulk density, pore-size distribution, particle-size distribution, aggregate stability, and others.

As part of a comprehensive research program to gather basic information on the soils of Puerto Rico, infiltration studies were systematically conducted from 1945 to 1957 . The data obtained have been published only in part and as part of other more comprehensive studies. Thus, Bonnet and Tirado-Sulsona $(3)^{2}$ published in 1950 some of the first data obtained in their soil studies of the Lajas Valley. During the same year Bonnet and Lugo-López ( $(1)$ published additional infiltration data as part of their soil studies in the projected Coamo irrigation area. In 1953, Lugo-López, et al. (5) published some more of these data in their study of the soils of the Island of Vieques. Data on the rate of infiltration of Latosols was also published by Bonnet and Lugo-López (2). Martínez and Lugo-López (8) conducted studies on the effect of subsoiling and mole drainage upon the minimum infiltration capacity of a heavy claypan soil. Lugo-López et al. (6), and Landrau et al. (4) studied the effect of various practices of handling sugarcane trash on soil properties, including infiltration rate. Also LugoLópez et al. (7) published additional data on their studies of the soils from east-central Puerto Rico.

This paper summarizes the bulk of the data on the rate of infiltration of Puerto Rican soils, most of it not previously published elsewhere.

1 Two Soil Scientists at the Department of Agronomy and Soils, and Former Head, Department of Soils, Agricultural Experiment Station, University of Puerto Rico, Mayagüez Campus, Rio Piedras, P.R. The authors wish to express their appreciation to the many members of the Station staff who participated in the field work. Among others, thanks are due Pedro Tirado-Sulsona, Fernando Abruña, Fausto MariotaTrías, Pablo Landrau, Jr., M. B. Martínez, R. Olivencia, H. Gandía-Diaz, E. Telford, and Alfonso Riera.

2 Numbers in parentheses refer to Literature Cited, p. 240. 


\section{MATERIALS AND METHODS}

Infiltration tests were run under field conditions in selected soils including 57 of the major soil series of the Island. Each test was run in quadruplicate at each site. Tests for most of the soil series were conducted at more than a single location for a total of 740 individual tests. The tests were run using the buffer compartment method as outlined by Nelson and Muckenhirn (9). The procedure is briefly as follows:

Three concentric iron rings, each 5 inches in height, and 9, 18 and 27 inches in diameter, are driven 2 or 3 inches into the ground. The soil inside the two outside rings is kept saturated with water while the test is running. The infltration test is run in the soil within the inner 9-inch ring, over which hangs a calibrated $2,000-\mathrm{ml}$. burette, the water reservoir. A volume of $1,043 \mathrm{ml}$. in this burette is equivalent approximately to 1 inch of water added to the 9-inch soil core. A pinchcock serves as a valve at the rubber hose that connects the tip of this burette to a small glass tube. The burette is filled with water to the 2,000-ml. mark and stoppered. The stopcock is opened and the starting time is recorded. Water infiltrates rapidly at first, into the soil, until the thin film of water that collects on the topsoil touches the end of the small tube. This film serves as a regulator for the water to run from the burette as fast as the soil requires it. The time is recorded every time the burette is emptied to the zero mark. At this time the pinchcock is closed rapidly and the burette is refilled with water. The outfit is kept covered with a canvas.

The tests were run for 8 consecutive hours. The amount of water used every hour was recorded.

\section{RESULTS AND DISCUSSION}

Table 1 presents data on the eighth-hour infiltration rate for each soil series studied including information on the number of tests for each mean value reported. The mean infiltration rates for Yunque, Vivi, and Alonso soils, were the highest values recorded. The value for Nipe clay, a product of intense laterization, was of the order of 6.16 inches per hour. The value for Catalina clay, a soil where laterization has been less intensive than in the Nipe, is 4.16 inches per hour. In general, there are 16 soils with values ranging from 4.04 to 11.49 inches. Among them, the alluvial soils of the San Antón, Viví, and Altura series are included. There are 11 soils with mean values above 3 , but not reaching 4 inches of water at the eighth hour. Múcara, a rather extensive soil of the uplands, is included in this group. Toa, a well-drained extensive alluvial sugarcane soil, is also included within this group. Among the soils in the 2- to 3-inch range is the Mabi clay, a rather extensive soil of the East-Central Region. Ten soil types are included in the next group ( 1 to 2 inches), including the extensive Coloso 
TABLE 1.-Eighth-hour infiltration rates for 57 soils of Puerto Rico

\begin{tabular}{|c|c|c|}
\hline Soil series & Tests & 8th-hour infiltration rate \\
\hline & Number & $I n . / h r$. \\
\hline Yunque & 12 & 11.49 \\
\hline Vivi & 4 & 10.99 \\
\hline Alonso & 4 & 9.47 \\
\hline Río Piedras & 8 & 7.83 \\
\hline Soller & 8 & 7.82 \\
\hline Nipe & 4 & 6.16 \\
\hline Camagüey & 4 & 6.05 \\
\hline Matanzas & 4 & 5.88 \\
\hline Arroyo 1 & 8 & 5.31 \\
\hline Estación & 4 & 5.29 \\
\hline San Antón & 28 & 4.70 \\
\hline Machete & 4 & 4.63 \\
\hline Vives & 4 & 4.59 \\
\hline Guayama & 8 & 4.47 \\
\hline Catalina ${ }^{2}$ & 20 & 4.16 \\
\hline Altura ${ }^{2}$ & 20 & 4.04 \\
\hline Moca & 4 & 3.90 \\
\hline $\mathbf{F e}$ & 8 & 3.83 \\
\hline Coto & 12 & 3.39 \\
\hline Lares $^{2}$ & 4 & 3.36 \\
\hline Toa & 36 & 3.29 \\
\hline Múcara & 12 & 3.26 \\
\hline Sabana & 4 & 3.26 \\
\hline Sabana Seca² & 4 & 3.16 \\
\hline Vieques & 36 & 3.12 \\
\hline Fajardo & 12 & 3.04 \\
\hline Plata & 4 & 3.00 \\
\hline Torres & 8 & 2.96 \\
\hline Tejas & 8 & 2.87 \\
\hline Vega Baja & 8 & 2.84 \\
\hline Caguas ${ }^{2}$ & 8 & 2.14 \\
\hline Las Piedras & 16 & 2.09 \\
\hline Mabi & 20 & 2.01 \\
\hline Coloso & 8 & 1.86 \\
\hline Juncos & 12 & 1.55 \\
\hline Candelero & 16 & 1.43 \\
\hline Caribe 1 & 4 & 1.30 \\
\hline Maunabo & 12 & 1.21 \\
\hline Fortuna & 8 & 1.11 \\
\hline Cayaguá & 16 & 1.11 \\
\hline Josefa & 20 & 1.10 \\
\hline Via & 52 & 1.01 \\
\hline Picacho & 4 & 1.00 \\
\hline Arenales ${ }^{1}$ & 4 & .93 \\
\hline Yauco & 12 & .85 \\
\hline
\end{tabular}


TABLE 1.-Continued

\begin{tabular}{l|c|c}
\hline \multicolumn{1}{c|}{ Soil series } & Tests & 8th-hour infiltration rate \\
\cline { 2 - 3 } & Number & In./hr. \\
Vega Alta & 4 & .81 \\
Santa Isabel & 20 & .66 \\
Fraternidad & 24 & .38 \\
Descalabrado & 36 & .36 \\
Coamo & 24 & .28 \\
Llave & 4 & .26 \\
Amelia & 36 & .19 \\
Jácana & 20 & .12 \\
Yabucoa & 4 & .07 \\
Aguirre & 24 & .07 \\
Palmas Altas & 4 & .01 \\
Britton & 20 & .01
\end{tabular}

1 New soil series tentatively recognized by the USDA Soil Conservation Service; series description pending formal approval.

2 The sites where these tests were conducted were originally mapped by the name used in this table and in the text, but upon revision they were designated as shown in the following tabulation:

$$
\begin{aligned}
\text { Catalina } & =\text { Humatas } \\
\text { Altura } & =\text { San Antón acid variant } \\
\text { Lares } & =\text { Voladora } \\
\text { Sabana Seca } & =\text { Sosa } \\
\text { Caguas } & =\text { Palmarejo }
\end{aligned}
$$

soils of the lowlands. The lower extreme (0.01 to 0.93 of an inch) includes such soils as Santa Isabel, Descalabrado, Coamo, Fraternidad, and Aguirre.

An overall examination of the data presented, as well as of that previously published, indicates wide differences as to soil infiltration per $s e$ and as to soil response, in terms of infiltration rate, to management practices. In the Lajas Valley area, Santa Isabel clay has a fair rate of infiltration while Aguirre and Fraternidad soils have very low rates (3).

The Coamo clay and related soils have slow infiltration rates after the soil has been thoroughly soaked, i.e., at the eighth hour. Laboratory data (1) show clearly that the layer which limits infiltration is immediately below the upper surface foot of soil, but above the uppermost gravel layer in the profile. This layer appeared to be the tightest upon fieldprofile examination, and this was confirmed under laboratory conditions. This tight layer in the upper part of the profile tends to limit water movement, while the underlying layers of gravel and sand are all very rapidly permeable, and do not have the capacity to hold much water available for crop use. This must be carefully considered in planning an irrigation system for the Coamo area. 
The soils of the Island of Vieques have a minimum infiltration capacity that can be rated as ranging from moderate to rapid. In an alluvial Viví soil, with considerable gravel underneath, the surface sandy loam has a very rapid infiltration rate, while a Yabucoa soil has a slow rate of infiltration at the eighth hour (5).

In a Caguas silt loam, where a subsoiling experiment was conducted, the rate of infiltration was 0.5 inch of water per hour in undisturbed sites. (8). Ordinary plowing and harrowing increased the infiltration tenfold. Subsoiling increased it to 26.7 inches. Areas of this soil occur usually in flat lands where larger volumes of runoff water from adjoining hills must be disposed of quickly. Thus, even with rains of small intensities, large quantities of water collect on low fields which may be very harmful to. growing crops unless internal drainage is very good. Subsoiling may assure a very rapid rate of infiltration.

The following values were obtained in an experiment on a Vega Alta silty clay (6) at Río Piedras where sugarcane trash was either burned, buried, or aligned in alternate rows for six consecutive years:

$\begin{array}{lc} & \text { Inches/hour } \\ \text { Trash burned } & 1.40 \\ \text { Trash aligned } & 2.00 \\ \text { Trash buried } & 2.38\end{array}$

In general, the soil infiltration was slower in the plots where the trash was burned than in those where it was either buried or aligned. Burying the trash disturbed these plots mechanically every year in the making of a furrow between cane rows which promoted a higher rate of infiltration. In a similar experiment in a Coto clay soil in Isabela (4) the following results were obtained:

$\begin{array}{lc} & \text { Inches/kour } \\ \text { Trash burned } & 1.10 \\ \text { Trash undisturbed } & 1.39 \\ \text { Trash aligned and clean } & 1.80 \\ \quad \text { banks furrowed } & \\ \text { Trash aligned } & 2.70\end{array}$

In general, the soil-infiltration rate was faster in the plots where the trash was aligned than in those where it was otherwise handled. The differences between the means of the treatments were significant. In all cases, the rate of infiltration at the eighth-hour was from moderate to moderately rapid. In an area where supplemental irrigation is necessary as in Isabela, a moderately rapid rate of infiltration may be a handicap. In this connection, the value of leaving the trash undisturbed over the 
surface soil may be of tremendous importance, insofar as it reduces the water losses by direct evaporation.

Table 2 gives the eighth-hour infiltration rate for the same soils listed in table 1, but in this case following a practical grouping developed at the Agricultural Experiment Station of the University of Puerto Rico, which is based on factors such as climate, relief, slope, and profile characteristics. All the soils of Puerto Rico have been classified into 28 groups; however,

TABLE 2.-Mean eighth-hour infiltration rate for 20 soil groups of Puerto Rico ${ }^{1}$

\begin{tabular}{c|c|c}
\hline Soil group & Tests & 8th-hour infiltration rate \\
\hline & Number & In./hr. \\
$5 w$ & 4 & 0.01 \\
$2 w$ & 4 & .81 \\
$17 \mathrm{t}$ & 64 & .94 \\
$1 \mathrm{f}$ & 8 & 1.11 \\
$1 w$ & 60 & 1.39 \\
$15 w$ & 24 & 1.44 \\
17 & 48 & 1.62 \\
9 & 28 & 1.92 \\
$4 w$ & 28 & 1.95 \\
8 & 24 & 2.00 \\
$15 \mathrm{i}$ & 144 & 2.87 \\
$10 \mathrm{t}$ & 40 & 2.87 \\
10 & 36 & 3.00 \\
13 & 36 & 3.71 \\
$2 \mathrm{i}$ & 16 & 4.26 \\
7 & 28 & 4.57 \\
1 & 96 & 5.14 \\
$7 \mathrm{t}$ & 36 & 5.74 \\
12 & 4 & 6.16 \\
11 & 12 & 7.82 \\
\hline
\end{tabular}

1 Grouping based on climate, slope, relief, and soil-profile characteristics.

infiltration data are available only for soils within 20 groups. The range of values in the original data are indicative of the large variations within the soil groups. The groups identified with a $w$, following a number, include soils with imperfect and poor drainage. The mean values for these soils are among the lowest, ranging from 0.01 for soils within group $5 w$ to 1.95 inches for soils within group $4 w$.

Table 3 gives eighth-hour infiltration values for the same soils now grouped according to the latest tentative classification system developed by the USDA Soil Conservation Service. Vertisols range from 0.07 to 3.83 inches, the lowest group. Entisols have higher infiltration rates ranging 
from minimum values of 0.93 to maximum values of 10.99 inches. Mollisols, with soft mineral surface soil, rank high in infiltration rates. Infiltration values for Oxisols and Ultisols, typical of the Humid Tropics, are among the highest.

\section{SUMMARY}

Data are presented here on the minimum rate of infiltration (eighth-hour) of 57 main soil types of Puerto Rico. The study included a total of 740 tests. Mean infiltration rates vary from a high value of 11.49 inches of water per hour in Yunque sandy loam, to a low of 0.07 in Aguirre clay, and 0.01 in Palmas Altas and Britton clay. When the soils were arranged according to a simple, practical classification system in use in Puerto Rico the mean

TABLE 3.-Minimum and maximum eighth-hour infiltration rate for soil orders of Puerto Rico according to Fith classification scheme ${ }^{1}$

\begin{tabular}{l|c|c}
\hline \multirow{2}{*}{ Soil order } & \multicolumn{2}{|c}{ Eighth-hour infiltration rates } \\
\cline { 2 - 3 } & Minimum & Maximum \\
\hline & In./hr. & In./hr. \\
Vertisols & 0.07 & 3.83 \\
Entisols & .93 & 10.99 \\
Inceptisols & 1.10 & 5.31 \\
Alfisols & 1.11 & 4.63 \\
Mollisols & 3.29 & 7.82 \\
Oxisols & 3.39 & 6.16 \\
Ultisols & 2.96 & 9.47 \\
\hline
\end{tabular}

1 Only those soils already recognized within these groups were included.

values ranged from 0.01 in group $5 w$ to 7.82 inches in group 11. When the soils were grouped following the latest classification system developed by the U.S. Department of Agriculture, mean values for soils included in the order Vertisol ranged from 0.07 to 3.83 inches. Mollisols, Oxisols, and Ultisols showed the highest infiltration values. Information is hereby given as to the effects of various soil treatments on infiltration rates.

\section{RESUMEN}

En este trabajo se presentan datos sobre la infiltración mínima (a la octava hora) de 57 de los suelos principales de Puerto Rico. El estudio incluyó 740 pruebas de infiltración. Se encontró que la infiltración media de los suelos de Puerto Rico varía de 11.49 pulgadas de agua por hora en el suelo Yunque lómico arenoso a un valor tan bajo como el de 0.07 en el suelo Aguirre arcilloso y 0.01 en las arcillas Palmas Atlas y Britton. Cuando los suelos se agruparon según una clasificación sencilla y práctica que se utiliza 
en Puerto Rico, los valores medios fluctuaron entre 0.01 para los suelos del grupo $5 w$ y 7.82 pulgadas de agua por hora para los del grupo 11. Al agruparse por órdenes de suelos según el más moderno sistema de clasificación, los suelos de la orden Vertisol fluctuaron en promedio entre 0.07 y 3.83 pulgadas de agua por hora. Los Mollisols, Oxisols y Ultisols alcanzaron los valores medios más altos. En este trabajo, también se ofrece información en cuanto a los efectos que tienen diversas prácticas de manejo de los suelos sobre la tasa de infiltración.

\section{LITERATURE CITED}

1. Bonnet, J. A., and Lugo-López, M. A., Soil studies in the projected Coamo irrigation area, Univ. P.R. Agr. Exp. Sta., Bull. 88, 1950.

2. - The rate of infiltration of lateritic soils, J. Agr. Univ. P.R. 36 (2): 161-6, 1952.

3. Bonnet, J. A., and Tirado-Sulsona, P., Soil studies in Lajas Valley, Univ. P.R. Agr. Exp. Sta. Bull., 86, 1950.

4. Landrau, Jr., P., Lugo-López, M. A., Samuels, G., and Silva, S., Leaving sugarcane trash undisturbed on a lateritic soil compares favorably with currently used trash-disposal methods, J. Agr. Univ. P.R. 38 (1): 1-8, 1954.

5. Lugo-López, M. A., Bonnet, J. A., and García, Jean, The soils of the Island of Vieques, Univ. P.R. Agr. Exp. Sta. Bull., 108, 1953.

6. - L Landrau, Jr., P., and Samuels, G., The handling of sugarcane trash. II: Effects of various practices on soil properties, J. Agr. Univ. P.R. 36 (3): 240-5, 1952.

7. - Martínez, M. B., and Riera, A. R., Morphological and physicochemical properties of various tropical soils from east-central Puerto Rico, J. Agr. Univ. P. R. 36 (2): 167-78, 1952.

8. Martínez, M. B., and Lugo-López, M. A., Tillage tests. I: Effect of subsoiling and mole drainage upon the minimum infiltration capacity of a heavy clay soil of the Tropics, J. Agr. Univ. P.R. 36 (2): 179-85, 1952.

9. Nelson, L. B., and Muckernhirn, R. J., Field percolation rates of four Wisconsin soils having different drainage characteristics, J. Amer. Soc. Agron. 38 (11): 1028-36, 1951.

10. Roberts, R. C. Soil Survey of Puerto Rico, USDA in cooperation with Univ. P.R. Agr. Exp. Sta., 1942. 